Revue Française de Civilisation Britannique

\title{
Interview with Alan Gibbons, Labour Party Activist
}

\section{Stéphanie Bory et Fiona Simpkins}

\section{OpenEdition}

\section{Journals}

Electronic version

URL: http://journals.openedition.org/rfcb/2195

DOI: $10.4000 /$ rfcb. 2195

ISSN: 2429-4373

\section{Publisher}

CRECIB - Centre de recherche et d'études en civilisation britannique

\section{Electronic reference}

Stéphanie Bory et Fiona Simpkins, «Interview with Alan Gibbons, Labour Party Activist », Revue Française de Civilisation Britannique [Online], XXIII-2 | 2018, Online since 14 September 2018, connection on 03 May 2019. URL : http://journals.openedition.org/rfcb/2195 ; DOI : 10.4000/ rfcb.2195

This text was automatically generated on 3 May 2019.

\section{cc) () $९$}

Revue française de civilisation britannique est mis à disposition selon les termes de la licence Creative Commons Attribution - Pas d'Utilisation Commerciale - Pas de Modification 4.0 International. 


\title{
Interview with Alan Gibbons, Labour Party Activist
}

\author{
Stéphanie Bory et Fiona Simpkins
}

1 Alan Gibbons is a member of Liverpool Walton Constituency Labour Party. He writes adult and children's fiction and is about to start work on a history of the Left in Liverpool. Alan Gibbons is a million-selling writer of over seventy books. He decided to join the Labour Party in 2015, and was involved in the 2017 campaign.

\section{Q: How long have you been a member of the Labour Party?}

2 I joined the Labour Party three years ago, inspired by the campaign to elect Jeremy Corbyn.

\section{Q: Why did you join in the first place?}

3 Between 1974 and 1996, I had been a member of a left-wing group outside the Labour Party. When I became disillusioned with that route, I was an individual campaigner for left and radical causes for two decades, especially as a writer. My children joined the Labour Party first. They recruited my wife and eventually their example drew me in. I was inspired by the hope of the youth. The main issue that clinched it was the need to defeat austerity. I had spent many hours on pickets, lobbies and demonstrations, opposing cuts to public services, but never winning. I became convinced, with all the reservations of my political past, that we needed to elect a socialist government. Then the fun begins!

\section{Q: Did you get involved in previous election campaigns? Which ones?}

4 I always voted Labour, but the last time I went out campaigning was in the 1970s. Since joining, hardly a week goes by without me leafletting or canvassing in some form. 


\section{Q: Have the Labour party's results in the $\mathbf{2 0 1 7}$ general elections consolidated Corbyn's position as leader?}

At the moment, Jeremy Corbyn is untouchable as leader. Nobody outside Labour's activist base expected anything other than a 100-seat Tory landslide at the General Election. Many of us out campaigning heard something different, a weariness with austerity, a desire for change. If the party machine had started out with a more aggressive strategy, rather than the defensive one many areas adapted, we might even have got a minority Labour government. When some on the backward-looking wing of the party tried to criticise for our local election results in May, they just looked stupid. That said, we need to consolidate the Left gains in the party machine and we must begin to shift the Parliamentary Labour Party to a more Corbyn-friendly outlook.

Q: Has the fragmentation of the working class vote and Labour's increasing reliance on younger, urban and pro-European voters weakened rather than strengthened its base or is it a positive sign for the party?

6 Some people predicted that Labour's refusal to back a second EU referendum- correct, in my opinion- would push some Remain voters into the arms of parties like the Liberal Democrats or the Greens. This has not happened. They have flatlined. People still remember the Lib Dems' slavish support for Tory austerity and the Greens just do not have a platform for electoral advance. The young see Labour as a bulwark against a Tory hard-Brexit and find Labour's more socially progressive outlook infinitely more appealing than the Tories' capitulation to far right isolationism.

\section{Q: Did Corbyn and Momentum manage to some degree to reconnect the Labour Party to the wider electorate?}

7 The Manifesto won over three million voters to Labour, especially in the big, urban areas. In my profoundly working class constituency, we polled $85.7 \%$ for Labour. Momentum succeeded in mobilising younger activists in substantial numbers, both on the doorstep and through phonebanking. Momentum's social media campaign hugely outflanked the dull and unconvincing Tory message.

\section{Q: To what extent was Brexit key to achieving this with some parts of the electorate? Were there other key issues?}

8 I find the European issue interesting. It played to some extent in London, but there it strengthened Labour because the Tories were so much further to the nationalist, anti-immigrant, anticosmopolitan right. Here in Liverpool Walton, the EU referendum vote was the same as the national one, 52-48 to leave, but the Labour vote increased. When we were campaigning very few people even mentioned Europe. They were more concerned with the NHS, jobs, wages and housing. It was a polarised election here. People rallied to Labour out of a class dislike of the Tories.

\section{Q: Did Labour's refusal to adopt a clear pro-European stance cost the party the 2017 general election? How divided is the British left over this issue?}

Definitely not. Austerity was the dominant issue. That is why the Manifesto, a defence of public service and hope for a better future, resonated. Theresa May said she would bury Labour. In fact, Labour had a twelve-point advance, the biggest shift in its direction since 1945. This was after two years of virtual civil war in the party, a remarkable result. In areas like mine, a pledge to reverse 
the result of the EU referendum or to call instantly for a second one would have repelled working class Labour voters who supported leaving the EU.

\section{Q: Is the internal rift between the Blair-supporting Movement for Change and the pro-Corbyn Momentum drowning out voices of the left in Britain?}

In the mass membership, there is very little support for the self-limiting defeatism of Blair nostalgia. Even many who are unsure about Jeremy Corbyn think privatisation, the Private Finance Initiative and obsession with the market were a disaster and must be consigned to the dustbin of history. In some of the selection battles, there are differing Left voices, some very pro-Momentum and others closer to the left of trade unions like Unite. There isn't just one Left. The Left in my constituency has come from various political traditions: militant trade unionism, community activism, feminism, people rejoining the Labour Party, people who despaired of the old 'outside Left' for its sectarianism and impotence. Only a minority are active in Momentum.

\section{Q: What impact did new technology tools and platforms as well as the growing emphasis placed on community organising have on the campaign?}

11 I think Labour won the social media battle hands down. It was a very useful organising tool and countered the relentlessly hostile corporate media. It gave a sense of a movement on an upward swing and one that was receptive to the young and to people often alienated by the stale old politics of pure electoralism. We should not exaggerate this, but activity in community and trade union campaigns helped energise people. For example, my constituency and others across the city are involved in food banks, homelessness campaigns, supporting those strikes that are happening, NHS campaigns, even little things like planting flowers with the local community groups to brighten up our working class communities. We are stepping up community campaigning. For example, locally we are doing litter picks to clean up areas because cuts to cleansing services are having a negative impact. We are showing films on left wing causes. We support local community charities improving the environment. It all comes together to lay the basis for the transformative movement from below we want Labour to be.

\section{Q: Would you say that recent efforts under Corbyn to adopt a more bottom-up approach to the organisation of Labour have succeeded in creating a mass movement ready for government or, on the contrary, reduced it to a protest group?}

12 It is the right way to go. Because much of the Parliamentary Party, many local councillors and sections of the party machine still look back to the Labour Party in its more top-down, neoliberal, self-limiting and moderate, recent past, the desire to refashion Labour as a rank-and-file, transformative political movement co-exists with a more conventional approach, the kind of approach that left much of the European Left (the French PS, the German SPD, the Italian left, Pasok) in electoral and organisational tatters. The Labour Party resisted that outcome by being more radical. If the local election results this month were repeated in a General Election, Labour would be the biggest party.

\section{Q: How do you foresee the outcome of the ongoing Brexit negotiations?}

The big issue in British politics was always neoliberal economics, the slow disintegration of British capitalism and the UK's decline as a world power. Part of the EU referendum result was a yearning for the culture of Empire, but it was a pathetic and reactionary nostalgia. I have always been of the 
opinion that nothing much would change and that we would end up formally outside the EU, but with a close relationship to some form of Customs Union and the single market. Nothing has changed my view. It is a modest rearrangement of the affairs of British capitalism. The incompetence and political coherence does mean that the Conservatives may haplessly blunder into a 'hard Brexit.' Political formations don't always act in their own interests. Labour has no need to short-circuit the process of developing its final position. The Tories are in office, not us. We should scrutinise their political failure, not try to take responsibility for it. 